\title{
Penatalaksanaan perdarahan saluran cerna bagian atas dengan nutrisi enteral dini terhadap kadar albumin
}

Management of upper gastrointestinal bleeding by early enteral nutrition on levels of albumin

\author{
Virgianti Nur Faridah', Farida ${ }^{2}$ \\ ${ }^{1}$ Prodi S1 Keperawatan STIKES Muhammadiyah Lamongan \\ ${ }^{2}$ Rumah Sakit Aisyiyah Bojonegoro
}

\begin{abstract}
Background: Patients with upper gastrointestinal bleeding generally were decreased nutritional status that hypoalbuminemia because of increased albumin excretion from hemorrhage and patients fasted indefinitely until the bleeding stops. Enteral nutrition in patients with bleeding should be given to prevent malnutrition and reduce mortality. Objective: To identify the differences in levels of albumin serum in the early enteral nutrition without waiting for the results of gastric lavage is clear (without fasting) and after 2-3 times the clear gastric lavage (fasted). Method: The study used pre-experimental research design by static-group comparison design. The study was conducted in RS Aisyiyah Bojonegoro in March to June 2015. The sample was 30 patients divided into 2 groups by random allocation, there were the treatment group I that fasted (15 patients) and treatment group II without fasted (15 patients). Analysis of data using Wilxocon test signed ranks test. Results: The research found that there was differences in the provision of early enteral nutrition to albumin. Results showed that albumin level in patients who fasted lower than that without fasted ( $p=0,046)$. Conclusion: Patients with upper gastrointestinal bleeding can be given early enteral nutrition without waiting for the results gastric lavage clear rinse.
\end{abstract}

KEY WORDS: albumin serum; early enteral nutrition; upper gastrointestinal bleeding

\begin{abstract}
ABSTRAK
Latar belakang: Pasien perdarahan saluran cerna bagian atas (SCBA) umumnya mengalami penurunan status gizi yaitu hipoalbuminemia karena adanya peningkatan pengeluaran albumin akibat perdarahan dan pasien yang dipuasakan tanpa batas waktu sampai perdarahan berhenti. Pemberian nutrisi enteral pada pasien perdarahan SCBA perlu diberikan untuk mencegah malnutrisi dan menurunkan mortalitas. Tujuan: Mengidentifikasi perbedaan kadar albumin pada pemberian nutrisi enteral dini (NED) tanpa menunggu hasil bilas lambung jernih (tanpa dipuasakan) dan setelah 2-3 kali hasil bilas lambung jernih (dipuasakan). Metode: Desain penelitian eksperimental dengan rancangan penelitian pra-eksperimental yaitu dengan metode static-group comparison design. Penelitian dilakukan di RS Aisyiyah Bojonegoro pada bulan Maret-Juni 2015. Sampel sebanyak 30 pasien dibagi menjadi 2 dengan random allocation yaitu pemberian nutrisi enteral pada kelompok perlakuan I yang dipuasakan (15 pasien) dan kelompok perlakuan II yang tanpa dipuasakan (15 pasien). Analisis data menggunakan Wilxocon signed-ranks test. Hasil: Ditemukan adanya perbedaan pemberian NED terhadap kadar albumin. Hasil penelitian menunjukkan kadar albumin pasien perdarahan SCBA yang dipuasakan lebih rendah dibandingkan dengan yang tanpa dipuasakan $(\mathrm{p}=0,046)$. Simpulan: Pasien perdarahan saluran cerna bagian atas dapat diberikan NED tanpa menunggu hasil bilas jernih.
\end{abstract}

KATA KUNCI: kadar albumin; nutrisi enteral dini; perdarahan saluran cerna bagian atas 


\section{PENDAHULUAN}

Penanganan perdarahan saluran cerna bagian atas (SCBA) yang disebabkan pecahnya varises gastroesofagus harus dilakukan dengan tepat dan cepat. Beberapa penatalaksanaan diantaranya dengan melakukan resusitasi cairan, endoskopi dini, pemberian obat-obatan, pemasangan nasogastric tube (NGT), serta menjaga pemenuhan kebutuhan nutrisi yang adekuat. Pasien dengan perdarahan SCBA merupakan pasien yang secara fisiologis tidak stabil, artinya sedikit saja terjadi perubahan pada salah satu organnya maka akan membawa dampak perubahan yang menyeluruh (sistemik) dan memungkinkan terjadi gagal organ multipel (1).

Di negara barat, kasus perdarahan gastrointestinal atas umumnya ditemukan sebagai kasus kegawatan dengan tingkat mortalitas 5-10\%, laki-laki lebih banyak daripada wanita dengan penyebab tersering ulkus peptikum (2-4). Insidensi ini meningkat sesuai dengan bertambahnya usia. Di Indonesia, kejadian yang sebenarnya di populasi tidak diketahui. Berdasarkan catatan medik pasien-pasien yang dirawat di bagian penyakit dalam Rumah Sakit (RS) 'Aisyiyah Bojonegoro pada tahun 2013, pasien yang dirawat karena perdarahan SCBA sebesar 2,5 - 3,5\% dari seluruh pasien yang dirawat di bagian penyakit dalam dengan penyebab terbanyak yaitu tukak peptik (35\%). Mortalitas secara keseluruhan masih tinggi yaitu sekitar 25\%. Sebagian besar penderita perdarahan SCBA meninggal bukan karena perdarahannya itu sendiri melainkan karena penyakit lain yang ada secara bersamaan seperti penyakit gagal ginjal, hipoalbuminemia, stroke, penyakit jantung, penyakit hati kronis, pneumonia, dan sepsis. Penyakit penyulit ini muncul disebabkan oleh kekebalan tubuh pasien mengalami penurunan, hal ini terjadi karena pemenuhan nutrisi enteral dini (NED) yang kurang adekuat (5).

Pada hampir semua pasien dengan perdarahan SCBA mengalami anoreksia atau tidak mampu makan karena penurunan kesadaran, pemberian sedasi atau terintubasi melalui saluran napas bagian atas. Pasien dengan perdarahan SCBA mengalami penurunan status gizi sehingga akan mempengaruhi kadar protein di dalam darah yang menyebabkan tubuh kekurangan asam amino esensial untuk mensintesis berbagai macam zat termasuk hormon (6). Jenis protein yang paling sering diukur adalah albumin serum. Level albumin yang rendah merefleksikan status nutrisi penderita yang dihubungkan dengan proses penyakit dan atau proses pemulihan (7).

Dukungan nutrisi sangat penting pada pengelolaan pasien dengan perdarahan SCBA dan dapat diberikan secara enteral, parenteral atau bersama-sama secara enteral dan parenteral. Apabila usus berfungsi baik, nutrisi diberikan dengan memakai konsep NED. Pada keadaan usus tidak berfungsi baik, maka bisa diberikan nutrisi parenteral atau nutrisi enteral dan parenteral bersama-sama sehingga kebutuhan kalori, cairan, mineral, dan trace element dapat terpenuhi (8). Nutrisi enteral adalah nutrisi yang diberikan pada pasien yang tidak dapat memenuhi kebutuhan nutrisinya melalui rute oral, formula nutrisi diberikan melalui tube ke dalam lambung (gastric tube), NGT, atau jejunum yang dapat dilakukan secara manual maupun dengan bantuan pompa mesin (8).

Beberapa sumber menyatakan bahwa nutrisi enteral dapat diberikan sedini mungkin untuk mencegah terjadinya kerusakan mukosa gaster dan vili-vili usus $(9,10)$. Jika diberikan secara dini, bantuan nutrisi bisa memberikan energi, protein, dan nutrisi yang diperlukan untuk mengoptimalkan sistem imun, meningkatkan penyembuhan luka, dan mencegah pemecahan masa lemak tubuh (8). Selama ini, penatalaksanaan pasien dengan perdarahan SCBA di ruang intensive care unit (ICU) RS 'Aisyiyah bojonegoro, baru akan diberikan NED setelah perdarahan SCBA berhenti yang ditandai dengan hasil bilas lambung 2 - 3 kali hasil jernih. Pasien dipuasakan tanpa terbatas waktu berapa hari hasil kumbah lambung menjadi jernih, jika terjadi hasil kumbah lambung pada NGT berwarna jernih maka menandakan lesi dalam lambung mengalami penyembuhan dan menandakan perdarahan tidak aktif. Sementara itu, pemberian NED berdampak positif dan berpengaruh signifikan dalam pemenuhan kebutuhan nutrisi pasien dan mencegah terjadinya atropi mukosa usus (11). Oleh karena itu, tujuan penelitian ini dilakukan adalah untuk mengidentifikasi perbedaan kadar albumin pada pemberian NED tanpa menunggu hasil bilas lambung jernih (tanpa dipuasakan) dan setelah 2-3 kali hasil bilas lambung jernih (dipuasakan). 


\section{BAHAN DAN METODE}

Penelitian ini merupakan penelitian eksperimental dengan rancangan static-group comparison design yang dilakukan di RS Aisyiyah Bojonegoro pada bulan Maret-Juni 2015. Populasi penelitian adalah seluruh pasien perdarahan SCBA di ruang ICU RS 'Aisyiyah Bojonegoro. Kriteria inklusi subjek adalah pasien perdarahan SCBA yang terpasang NGT untuk diberikan NED di ruang ICU RS 'Aisyiyah Bojonegoro, usia dewasa lebih dari 40 tahun, mendapat pemeriksaan albumin, dan bersedia menjadi subjek penelitian dengan bersedia menandatangani lembar informed consent. Sementara kriteria eksklusi subjek adalah pasien koma atau pasien dengan penyakit komplikasi berat seperti penyakit hati, ginjal, dan gagal jantung.

Metode sampling yang digunakan adalah consecutive sampling (12). Besar sampel dihitung berdasarkan rumus dengan tingkat kepercayaan 95\%; proporsi (p) sebesar 0,05 ; nilai d sebesar 0,05 ; dan besar populasi $(\mathrm{N})$ sebesar 38 sehingga diperoleh jumlah sampel minimal sebanyak 30 pasien yang kemudian dibagi menjadi dua kelompok dengan random allocation yaitu dengan cara acak melalui kertas undian yang bertuliskan kelompok I dan II. Setiap ada pasien yang memenuhi kriteria inklusi, dilakukan pengocokan kertas undian, pasien tersebut masuk kelompok I atau II sesuai hasil kocokan yang keluar. Pembagian kelompok tersebut yaitu 15 pasien kelompok perlakuan I dengan pemberian NED setelah 2-3 kali hasil bilas lambung jernih (dipuasakan) dan 15 pasien kelompok perlakuan II adalah pemberian NED tanpa menunggu hasil bilas lambung jernih (tanpa dipuasakan).

Variabel yang diteliti dalam penelitian ini terdiri dari variabel dependen yaitu kadar albumin serum yang dibagi menjadi tiga kriteria yaitu kadar albumin rendah $(<3,4 \mathrm{~g} / \mathrm{dL})$; kadar albumin normal $(3,4-4,7 \mathrm{~g} / \mathrm{dL})$; dan kadar albumin tinggi (>4,7 g/dL). Dalam hal ini, kadar serum albumin kurang dari 3,5 g/dL dikategorikan mengalami hipoalbuminemia (13). Sementara variabel independen (bebas) adalah pemberian NED yang dibagi menjadi dua kelompok yaitu kelompok I dengan pemberian nutrisi enteral setelah 2-3 kali hasil bilas lambung jernih (dipuasakan) dan kelompok perlakuan II adalah pemberian NED tanpa menunggu hasil bilas lambung jernih (tanpa dipuasakan).
Pengukuran kadar albumin serum dilakukan di laboratorium RS Aisyiyah Bojonegoro dengan pengambilan darah beku sejumlah $2 \mathrm{cc}$. Metode pengukuran laboratorium menggunakan metode bromocresol green (BCG). Pengukuran serum albumin dilakukan dua kali yakni sebelum perlakuan pemberian nutrisi enteral dan setelah pemberian nutrisi enteral pada kedua kelompok. Peneliti dalam hal ini melihat hasil albumin pada pasien perdarahan SCBA yang diberikan NED tanpa menunggu hasil bilas jernih (hanya dipuasakan 6-12 jam) dengan yang dipuasakan sampai 2-3 kali hasil bilas lambung jernih tanpa memperhatikan lamanya puasa. Sementara untuk intervensi pemberian nutrisi enteral dilakukan dalam bentuk diet nasi tim tinggi albumin (ikat gabus dan putih telur) yang diblender dan dimasukkan melalui selang NGT (berdasarksn diet dari ahli gizi RS Aisyiyah Bojonegoro). Pemberian diet tinggi albumin tersebut dilakukan oleh perawat ICU RS 'Aisyiyah Bojonegoro sebanyak 3 kali per hari selama 2-3 hari sesuai dengan kolaborasi dengan ahli gizi RS Aisyiyah Bojonegoro.

Uji statistik bivariat menggunakan Wilxocon signed-ranks test dengan tingkat kemaknaan 0,05 untuk melihat pengaruh variabel bebas terhadap variabel terikat (14). Penelitian ini dilaksanakan setelah mendapatkan surat ethical clearance penelitian dari Komite Penelitian RS Aisyiyah Bojonegoro.

\section{HASIL}

Karakteristik subjek penelitian berdasarkan Tabel 1 menunjukkan bahwa sebagian besar subjek (63\%) berjenis kelamin laki-laki. Umur yang paling banyak dijumpai adalah umur 61-70 tahun (43\%) diikuti dengan umur 51-60 tahun (34\%) dan sebagian besar penyebab perdarahan SCBA pada subjek penelitian ini adalah peptic ulcer $(56,67 \%)$.

Kadar albumin pasien perdarahan SCBA sebelum pemberian nutrisi enteral didapatkan jumlah yang sama antara dua kelompok yaitu sebagian besar subjek memiliki kadar albumin rendah (73,3\%). Namun, setelah intervensi didapatkan sebagian besar pasien pada kelompok I mempunyai kadar albumin rendah (67\%) sedangkan pada kelompok II yang diberikan NED setelah 
Tabel 1. Karakteristik subjek dan distribusi kadar albumin berdasarkan kelompok perlakuan

\begin{tabular}{lcccccc}
\hline \multirow{2}{*}{ Variabel } & \multicolumn{2}{c}{$\begin{array}{c}\text { Kelompok I } \\
(\mathbf{n}=\mathbf{1 5})\end{array}$} & \multicolumn{2}{c}{ Kelompok II } & \multicolumn{2}{c}{ Total } \\
\cline { 2 - 7 } & $\mathbf{n}$ & $\mathbf{\%}$ & $\mathbf{n}$ & $\mathbf{\%}$ & $\mathbf{n}$ & $\mathbf{\%}$ \\
\hline Jenis kelamin & & & & & & \\
$\quad$ Laki-laki & 10 & 33 & 9 & 30 & 19 & 63 \\
$\quad$ Perempuan & 5 & 17 & 6 & 20 & 11 & 37 \\
Usia (tahun) & & & & & & \\
$\quad 41-50$ & 3 & 10 & 1 & 3 & 4 & 13 \\
51-60 & 4 & 14 & 6 & 20 & 10 & 34 \\
$\quad 61-70$ & 7 & 23 & 6 & 20 & 13 & 43 \\
$\quad$ 70 & 1 & 3 & 2 & 7 & 3 & 10 \\
Penyebab & & & & & & \\
$\quad$ Peptic ulcer & 9 & 30 & 8 & 27 & 17 & 57 \\
$\quad$ Erosive gastritis & 5 & 17 & 5 & 17 & 10 & 33 \\
$\quad$ Lainnya & 1 & 3 & 2 & 6 & 3 & 10 \\
Kadar albumin pre & & & & & & \\
$\quad$ Rendah & 11 & 37 & 11 & 37 & 22 & 73 \\
$\quad$ Normal & 4 & 13 & 4 & 13 & 8 & 27 \\
$\quad$ Tinggi & 0 & 0 & 0 & 0 & 0 & 0 \\
\hline
\end{tabular}

Kelompok I = pemberian nutrisi enteral setelah 2-3 kali hasil bilas lambung jernih (dipuasakan); Kelompok II = pemberian NED tanpa menunggu hasil bilas lambung jernih (tanpa dipuasakan)

6-12 jam tanpa menunggu hasil bilas lambung bersih didapatkan sebagian besar kadar albumin normal $(60 \%)$. Hal ini didukung oleh hasil uji Wilxocon signed-ranks test yang menunjukkan nilai signifikan sebesar 0,046 $(\mathrm{p}<0,05)$ sehingga hipotesis diterima yaitu ada perbedaan pemberian NED terhadap kadar albumin pada pasien perdarahan SCBA yang dipuasakan dan tidak dipuasakan (Tabel 2).

\section{BAHASAN}

\section{Karakteristik subjek}

Berdasarkan karakteristik subjek diketahui bahwa kejadian perdarahan SCBA 1,73 kali lebih banyak terjadi pada laki-laki daripada perempuan dan umur yang paling banyak dijumpai adalah umur 61-70 tahun. Hasil studi sebelumnya menunjukkan bahwa pasien yang paling sering mengalami perdarahan SCBA berada pada usia 50-69 tahun dengan rerata usia 55 tahun $(\mathrm{SD} \pm 13)$ dan lebih sering ditemukan pada pria. Kondisi tersebut terkait dengan konsumsi analgesik yaitu $45 \%$ adalah jamu tradisional dan $12,5 \%$ adalah
Tabel 2. Perbedaan pemberian NED terhadap kadar albumin pasien SCBA

\begin{tabular}{lccccccc}
\hline \multirow{2}{*}{ Pemberian NED } & \multicolumn{6}{c}{ Kadar albumin } & \multirow{2}{*}{$\mathbf{p}^{\mathbf{1}}$} \\
\cline { 2 - 7 } & \multicolumn{1}{c}{ Tinggi } & \multicolumn{1}{c}{ Normal } & \multicolumn{2}{c}{ Rendah } & \\
\cline { 2 - 6 } & $\mathbf{n}$ & $\%$ & $\mathbf{n}$ & $\mathbf{\%}$ & $\mathbf{n}$ & $\mathbf{\%}$ & \\
\hline $\begin{array}{l}\text { Kelompok I } \\
\text { dipuasakan) }\end{array}$ & 0 & 0 & 5 & 33 & 10 & 67 & 0,046 \\
$\begin{array}{l}\text { Kelompok II (tanpa } \\
\text { dipuasakan) }\end{array}$ & 0 & 0 & 9 & 60 & 6 & 40 & \\
\hline
\end{tabular}

${ }^{1}$ bermakna $(\mathrm{p}<0,05)$; uji Wilxocon signed-ranks

nonsteroidal anti-inflammatory drugs (NSAID) (15). Kejadian perdarahan SCBA akibat ulkus lambung adalah umum ditemukan, terutama pada kelompok usia lanjut yaitu sekitar 68\% lebih dari 60 tahun dan 27\% lebih dari 80 tahun (16). Penyebab perdarahan SCBA terbanyak adalah tukak peptik $(56,67 \%)$. Hasil penelitian sebelumnya menemukan bahwa 104 kasus $(52 \%)$ dari 200 kasus perdarahan SCBA disebabkan untuk ulkus peptikum dan 96 kasus (48\%) untuk erosive gastritis (17). Penelitian yang dilakukan di RS Cipto Mangunkusumo, menganalisis pasien dengan perdarahan SCBA dan menemukan bahwa $50 \%$ disebabkan oleh ulkus peptikum dan erosive gastritis (18). Sementara penyebab paling umum untuk nonvarises perdarahan gastrointestinal atas adalah ulkus lambung $(2,3,4)$.

Kadar serum albumin subjek penelitian ini sebelum diberikan nutrisi enteral didapatkan sebagian besar tergolong rendah atau hipoalbuminemia. Level albumin yang rendah merefleksikan status nutrisi penderita yang dihubungkan dengan proses penyakit dan atau proses pemulihan (19). Hipoalbuminemia sering dihubungkan dengan lamanya pemulihan fungsi usus dan komplikasi lanjut gastrointestinal dan kadar albumin merefleksikan status gizi pada pasien yang menjalani rawat inap dalam jangka waktu lama $(20,21)$. Selain itu, kadar albumin yang rendah juga berhubungan dengan memanjangnya lama rawat inap total di rumah sakit atau memanjangnya lama rawat inap pascaoperasi $(21,22)$. Hipoalbuminemia sangat berhubungan kuat terhadap hasil klinis yang buruk (23). Kadar serum albumin yang diukur pada hari pertama menjalani proses rawat inap merupakan alat untuk memperkirakan kejadian kematian di rumah sakit, infeksi nosokomial, dan lama rawat inap (24). Penemuan bahwa pasien-pasien malnutrisi mengalami lama rawat 
inap yang lebih panjang dan menghabiskan biaya lebih tinggi secara signifikan, juga telah terdokumentasi (25). Tidak jarang malnutrisi ini timbul selama dirawat inap di rumah sakit. Penurunan status gizi pada pasien rawat inap, tanpa melihat status gizi pada saat masuk rumah sakit telah dilaporkan berhubungan dengan biaya lebih tinggi dan lama rawat inap lebih panjang (25). Perubahan status gizi subjek dari baik menjadi sedang, baik menjadi buruk, dan sedang menjadi buruk berpengaruh secara signifikan terhadap lama rawat inap yang lebih panjang dibandingkan dengan subjek yang berstatus gizi baik selama dirawat inap di rumah sakit. Demikian juga dengan subjek berstatus gizi dari baik menjadi sedang dan baik menjadi buruk mengeluarkan biaya yang lebih besar dibandingkan dengan subjek yang berstatus gizi baik selama dirawat inap di rumah sakit (26). Status hipoalbuminemia pra-operasi mempengaruhi terjadinya komplikasi pasca-operasi terutama kejadian infeksi pasien yang akan menjalani operasi elektif (27). Oleh karena luasnya dampak tersebut, maka perlu kiranya diberikan dukungan nutrisi enteral.

\section{Pemberian NED terhadap kadar albumin pada pasien perdarahan SCBA}

Kadar albumin pada pasien perdarahan SCBA yang dipuasakan yaitu menunggu 2-3 kali hasil bilas lambung jernih tanpa terbatas berapa hari pasien harus berpuasa menunjukkan hasil albumin normal hanya pada sebagian kecil subjek $(33,3 \%)$ sedangkan sebagian besar sisanya memiliki kadar albumin rendah (66,7\%). Sementara itu, pada subjek perlakuan yaitu pasien tidak dipuasakan (6-12 jam) tanpa menunggu hasil bilas jernih yang diberi NED dengan diet cair ekstra kutuk 3 kali sehari selama 2-3 hari menunjukkan kadar albumin normal pada sebagian besar subjek (60\%). Berdasarkan data ini, terjadi penurunan persentase pada albumin rendah jika pasien segera diberikan NED tanpa dipuasakan dan tanpa menunggu hasil bilas jernih. Hasil analisis juga menunjukkan bahwa ada perbedaan yang signifikan $(p=0,046)$ antara pasien perdarahan saluran cerna bagian atas yang dipuasakan dan tidak dipuasakan terhadap kadar albumin darah.

Beberapa pendapat menyatakan nutrisi enteral pada pasien perdarahan SCBA baru akan diberikan hanya setelah perdarahan SCBA berhenti yang ditandai hasil cairan bilas lambung dua kali jernih, dengan alasan bahwa pemberian nutrisi enteral dapat mempengaruhi tekanan vena porta dan menyebabkan perdarahan SCBA berulang $(9,10)$. Alasan tersebut juga dikaitkan dengan adanya peningkatan motilitas gaster dan usus yang disebabkan adanya proses pencernaan dimulai dari ingestion, mechanical processing, digestion, secretion, absorbs secara patofisiologi dapat meningkatkan tekanan intra abdomen dan selanjutnya meningkatkan tekanan vena porta dan bila hal ini terus berlanjut maka dapat terjadi varises esophagus yang selanjutnya dapat pecah dan terjadi perdarahan SCBA berulang $(28,29)$. Perdarahan yang berasal dari SCBA terjadi ketika ada ulkus mengikis dinding pembuluh darah. Pengikisan di mukosa harus disembuhkan dulu dengan obat-obatan antasida. Sel epithelium mukosa gastroduodenum dilindungi dari potensi efek merusak sekresi lambung, obat-obatan, alcohol, dan bakteri (29).

Selama ini penatalaksanaan pasien dengan perdarahan SCBA, baru akan diberikan NED setelah perdarahan SCBA berhenti yang ditandai dengan hasil bilas lambung 2 - 3 kali hasil jernih. Pasien dipuasakan tanpa terbatas waktu berapa hari hasil kumbah lambung menjadi jernih. Apabila terjadi hasil kumbah lambung pada NGT berwarna jernih menandakan lesi dalam lambung mengalami penyembuhan dan menandakan perdarahan tidak aktif. Namun, hasil penelitian didapatkan bahwa pasien dengan perdarahan SCBA yang diberikan nutrisi enteral menunggu hasil bilas lambung bersih 2-3 kali tanpa memperhatikan berapa hari pasien dipuasakan akan memiliki kadar albumin rendah dengan jumlah yang lebih banyak daripada pasien dengan kadar albumin normal. Hal ini disebabkan oleh pemenuhan protein akan mengalami keterlambatan sedangkan untuk proses penyembuhan penyakit sangat membutuhkan protein terutama albumin. Fungsi albumin adalah bermanfaat dalam pembentukan sel baru sehingga dapat mempercepat proses penyembuhan pasien. Selain itu, fungsi lain albumin yaitu dapat mengurangi bahkan menghilangkan edema jika terjadi peningkatan tekanan koloid osmotik karena adanya penumpukan cairan di ekstraselular. Hal ini disebabkan albumin dapat mengikat cairan ekstraselular masuk ke intraselular (30). 
Beberapa kondisi yang dapat terjadi pada pasien jika waktu puasa memanjang adalah lambung dalam kondisi kosong lama sehingga dapat meningkatkan sekresi asam lambung, pepsin, dan dapat menyebabkan refluknya cairan asam lambung serta menyebabkan mukosa gaster lebih sensitif terhadap asam lambung (31). Penelitian lain menyatakan bila terjadi pengosongan gaster terlalu lama lebih dari 24 jam, dapat terjadi translokasi bakteri dan selanjutnya dapat terjadi infeksi Helicobacter pylori (31). Berdasarkan kriteria dari European Society for Clinical Nutrition and Metabolism (ESPEN), disebutkan bahwa pasien walaupun tanpa keadaan kurang gizi, tetapi tidak dapat makan selama lebih dari 7 hari dan pasien yang tidak dapat memenuhi kebutuhan asupan secara oral ( $>60 \%$ ) selama lebih dari 10 hari dianjurkan mendapatkan dukungan nutrisi (32).

Nutrisi enteral merupakan salah satu terapi tambahan pada pasien penyakit kritis dengan fungsi gastrointestinal baik namun asupan oral tidak dapat diberikan. Keuntungan nutrisi enteral adalah meningkatkan integritas mukosa intestinal dalam absorbsi nutrisi, memperbaiki respon metabolik dan imun, menurunkan risiko komplikasi, serta harga yang lebih murah jika dibandingkan dengan nutrisi parentral (33). Pemberian NED berdampak positif dan berpengaruh signifikan dalam pemenuhan kebutuhan nutrisi pasien dan mencegah terjadinya atropi mukosa usus (11). Nutrisi enteral justru memberikan perlindungan pada got (saluran cerna) dan mukosa usus serta mengurangi perdarahan SCBA lebih lanjut (34). Early enteral nutrition juga mempunyai keuntungan mengurangi komplikasi septik. Pada binatang, enteral feeding akan mencegah atrofi saluran cerna dan mempertahankan gut barrier yang mencegah translokasi bakteri. Apabila translokasi bakteri tidak terjadi pada manusia, kerusakan gut barrier dapat menimbulkan pelepasan sitokin dan complement, dimulainya systemic inflammatory response syndrome (SIRS). Enteral feeding juga mempertahankan produksi secretory $\operatorname{Ig} \mathrm{A}$ ( $\mathrm{IIg} \mathrm{A})(35)$.

Nutrisi merupakan kebutuhan utama pasien kritis dan nutrisi enteral lebih baik dibandingkan parenteral karena lebih mudah, murah, aman, fisiologis, dan penggunaan nutrien oleh tubuh lebih efisien. Nutrisi enteral adalah nutrisi yang diberikan pada pasien yang tidak dapat memenuhi kebutuhan nutrisinya melalui rute oral, formula nutrisi diberikan melalui tube ke dalam lambung (gastric tube), nasogastric tube (NGT), atau jejunum dapat secara manual maupun dengan bantuan pompa mesin (8). Pemberian nutrisi enteral sebaiknya diatur sesuai dengan usia pasien, berat badan, penyakit primer, status nutrisi, alat akses nutrisi enteral tersebut, serta kondisi dari saluran gastrointesinalnya sendiri (36).

Pasien dengan status gizi yang buruk (misalnya penurunan berat badan dan hipoalbuminemia) harus diberikan terapi nutrisi selama 7 sampai 10 hari dan lebih baik diberikan dalam bentuk nutrisi enteral (37). Bahkan, hasil penelitian meta-analisis menunjukkan pemberian nutrisi enteral berhubungan dengan penurunan kejadian komplikasi sepsis dibandingkan pemberian nutrisi parenteral, mengurangi biaya rumah sakit, dan mengurangi lama rawat inap sehingga nutrisi enteral sebisa mungkin menjadi pilihan yang utama (38). Hasil systematic review juga menunjukkan bahwa penggunaan nutrisi enteral dibandingkan dengan hasil nutrisi parenteral penting dalam penurunan kejadian komplikasi infeksi pada penyakit kritis dengan biaya yang lebih murah. Nutrisi enteral harus menjadi pilihan pertama untuk dukungan nutrisi dalam penyakit kritis (39). Nutrisi enteral yang diberikan pada masa pasca tindakan operasi cenderung memberikan respon yang baik terhadap perubahan status nutrisi, nilai pre-albumin, dan albumin serum yang cenderung meningkat pada sebagian besar subjek dan tidak terjadi penurunan berat badan (40).

Nutrisi enteral dapat diberikan dalam waktu 6 jam setelah masuk ke ICU guna meningkatkan permeabilitas usus dan dikaitkan dengan penurunan kejadian kegagalan organ sedangkan pada pasien trauma nutrisi enteral dapat dimulai 24 jam setelah masuk $(41,42)$. Pemberian NED berupa diet blender ekstra kutuk dapat memperbaiki fungsi saluran cerna yang ditandai dengan hasil bilas lambung jernih dan rerata kadar albumin darah mengalami peningkatan berkisar $1,5 \mathrm{mg} / \mathrm{dl}$ dalam waktu 2-3 hari selama pemberian. Ikan gabus atau kutuk diketahui mengandung senyawa-senyawa penting bagi tubuh manusia diantaranya protein yang cukup tinggi, lemak, air, dan mineral terutama mineral zink (Zn). Zink berfungsi sebagai antioksidan yang melindungi sel-sel, 
mempercepat proses penyembuhan luka, mengatur ekspresi dalam limfosit dan protein, memperbaiki nafsu makan, dan stabilisasi berat badan (43). Ikan kutuk juga memiliki keunggulan yaitu kandungan 70\% protein, $21 \%$ albumin, asam amino yang lengkap, mikronutrien zink, selenium, dan besi (44).

\section{SIMPULAN DAN SARAN}

Penanganan perdarahan SCBA untuk mendapatkan status gizi yang lebih baik (kadar albumin meningkat) yaitu dengan pemberian NED yang tinggi albumin pada 6-12 jam tanpa dipuasakan menunggu hasil bilas lambung bersih. Perawat dapat berkolaborasi dengan ahli gizi dan tim medis dalam penentuan status nutrisi, komposisi diet nutrisi enteral dini, rute, dan cara pemberian sesuai dengan kondisi saluran gastrointestinal pasien. Penelitian lanjutan bisa dilakukan pada pasien perdarahan SCBA untuk melihat pengaruh pemberian NED pada penyembuhan perdarahan saluran cerna (efek hemostatis), perubahan kimia darah pasien lainnya (Hb, BUN, kreatinin, AST, ALT), tingkat toleransi pasien, lama rawat inap, dan komplikasi yang muncul.

\section{Pernyataan konflik kepentingan}

Penulis menyatakan tidak ada konflik kepentingan dengan pihak-pihak yang terkait dalam penelitian ini.

\section{RUJUKAN}

1. Adi, P. Pengelolaan perdarahan saluran cerna bagian atas. Buku Ajar Ilmu Penyakit Dalam (edisi IV Jilid I) (291294). Jakarta: Pusat Penerbitan Departemen Ilmu Penyakit Dalam FK-UI; 2006.

2. Barkun A, Sabbah S, Enss R, Redorak RN Amstrong D, Gregor J, et al. Canadian registry on non-variceal upper gastrointestinal bleeding and endoscopy (RUGBE): endoscopic hemostasis and proton pump inhibition are associated with improved outcomes in a real-life setting. Am J Gastroenterol 2004;99:1238-46.

3. Lewis JD, Bilker WB, Brensinger C, Farrajt, Strom BL. Hospitalization and mortality rates from peptic ulcer disease and GI bleeding in the 1990s: relationship to sales of nonsteroidal anti-inflammatory drugs and acid suppression medications. Am J Gastroenterol 2002;97:2540-9.

4. Lim CH, Vani D, Shah SG, Everett SM, Rembacken BJ. The outcome of suspected upper gastrointestinal bleeding with 24-hour access to upper gastrointestinal endoscopy: a prospective cohort study. Endoscopy 2006;38:581-5.

5. Sudoyo, Aru W, Setiyohadi, Alwi, Simadibrata, dkk. Buku ajar ilmu penyakit dalam. Jakarta: Penerbit Departemen Ilmu Penyakit Dalam Fakultas Kedokteran Universitas Indonesia; 2006.

6. Roche M, Rondeau P, Singh NR, Tarnus E, Bourdon E. The Antioxidant properties of serum albumin. FEBS Lett 2008;582(13):1783-7.

7. Wiryana M. Ventilator associated pneumonia. J Peny Dalam 2007;8(3):254-68.

8. Soejono $\mathrm{CH}$, Setiati S, Wiwie. Pedoman pengolahan kesehatan pasien geriatri: untuk kedokteran dan perawat. Jakarta: Penerbit FK UI; 2000.

9. Daldiono H, Syam AF. Dasar-dasar nutrisi klinik pada proses penyembuhan penyakit. Buku Ajar Ilmu Penyakit Dalam (edisi IV Jilid I) (56-59). Jakarta: Pusat Penerbitan Departemen Ilmu Penyakit Dalam FK-UI; 2006.

10. Daldiono H, Syam AF, Ingyanti S. Dukungan nutrisi pada kasus penyakit dalam nutrisi pada penyakit ulkus peptikum. Jakarta: Pusat Penerbitan Departemen Ilmu Penyakit Dalam FK-UI; 2006.

11. Moenadjat Y. Petunjuk praktis penatalaksanaan luka bakar. Asosiasi Luka Bakar Indonesia. Jakarta: Komite Medik Asosiasi Luka Bakar Indonesia; 2005.

12. Arikunto, Suharsimi. Prosedur penelitian suatu pendekatan praktik. Jakarta: Rineka Cipta; 2006.

13. Gupta D, Lis CG. Pretreatment serum albumin as a predictor of cancer survival: a systematic review of the epidemiological literature. Nutr J 2010;9:69.

14. Nursalam. Konsep dan penerapan metodologi penelitian ilmu keperawatan: pedoman skripsi, tesis dan instrument penelitian keperawatan. Jakarta: Salemba Medika; 2008.

15. Siregar L, Rani AA, Manan C, Simadibrata M, Makmun D. Clinical profile and outcome of non-variceal upper gastrointestinal bleeding in relation to timing of endoscopic procedur in patients undergoing elective endoscopy. Indones J Gastroenterol Hepatol Digest Endosc 2011;12(3):140-5.

16. Ohmann C, Imhof M, Ruppert C, Janzik U, Vogt C, Frieling $\mathrm{T}$, et al. Time-trends in the epidemiology of peptic ulcer bleeding. Scand J Gastroenterol 2005;40:914-20.

17. Syam AF, Setiawati A. Safety and efficacy of lansoprazole injection in upper gastrointestinal bleeding: a postmarketing surveillance conducted in Indonesia. Acta Med Indones 2013;45(2):123-9.

18. Syam AF, Abdullah M, Makmun D, et al. The causes of upper gastrointestinal bleeding in the national referral hospital: evaluation on upper gastrointestinal tract endoscopic result in five years period. Indones J Gastroenterol Hepatol Digest Endosc 2005;6:71-4. 
19. Supriyanta. Pengaruh Suplementasi Modisco Putih Telur Terhadap Perubahan Kadar Albumin Dalam Darah Pasien Bedah dengan Hipoalbumin di IRNA Bedah RSUP Dr. kariadi Semarang. [URL: http://repository.ums.co.id] 2010 [cited tanggal 11 Januari 2015]

20. Lim CH, Vani D, Shah SG, Everett SM, Rembacken BJ. The outcome of suspected upper gastrointestinal bleeding with 24- hour access to upper gastrointestinal endoscopy: a prospective cohort study. Endoscopy 2006;38:581-5.

21. Lohsiriwat V, Lohsiriwat D, Boonnuch W, Chinswangwatanakul V, Akaraviputh T, Lert- akayamanee $\mathrm{N}$. Pre-operative hypoalbuminemia is a major risk factor for postoperative complications following rectal cancer surgery. World J Gastroenterol 2008;14(8):1248-51.

22. Reddy KM, Meyer CER, Palazzo FF, Conaghan P, Blunt MC, Stebbings WSL, Leicester RJ, Cullen PT. Postoperative stay following colorectal surgery: a study of factors associated with prolonged hospital stay. Ann R Coll Surg Engl 2003;85(2):111-4.

23. Vincent JL, Dubois MJ, Navickis RJ, Wilkes MM. Hypoalbuminemia in acute illness: is there a rationale for intervention? a meta-analysis of cohort studies and controlled trials. Ann Surg 2003;237(3):319-34.

24. Delgado-Rodríguez M, Medina-Cuadros M, Gómez-Ortega A, Martínez-Gallego G, Mariscal-Ortiz M, MartinezGonzalez MA, Sillero-Arenas M. Cholesterol and serum albumin levels as predictors of cross infection, death and length of hospital stay. Arch Surg 2002;137(7):805-12.

25. Braunschweig C, Gomez S, and Sheean PM. Im- pact of declines in nutritional status on outcomes in adult patients hospitalized for more than 7 days. J Am Diet Assoc 2000;100:1316-22.

26. Reddy KM, Meyer CER, Palazzo FF, Conaghan P, Blunt MC, Stebbings WSL, Leicester RJ, Cullen PT. Postoperative stay following colorectal surgery: a study of factors associated with prolonged hospital stay. Ann R Coll Surg Engl 2003;85(2):111-4.

27. Yohanes Benny, Teguh Aryandono, Susetyowati. Hipoalbuminemia praoperasi pasien kanker kolorektal terhadap risiko komplikasi pascaoperasi dan lama rawat inap. Jurnal Gizi Klinik Indonesia 2013;9(4):170-178.

28. Martini. Fundamentals Of Anatomy And Physiology Edition, Upper Sadle River. Jersey. Prestice Hall, Inc; 2006

29. Price dan Wilson. Konsep Klinis Proses-Proses Penyakit. Edisi 6,vol 2. Jakarta: EGC; 2005.

30. Supariasa. Gizi dalam Masyarakat. Jakarta: PT. Elex Media; 2001
31. Ho KY and Kang JY. Esophageal mucosal acid sensitivityNormal or abnormal?, AJG. 2000;35:310-311.

32. Susetyowati, Ija M, Makhmudi A. Status gizi pasien bedah mayor preoperasi berpengaruh terhadap penyembuhan luka dan lama rawat inap pascaoperasi di RSUP Dr Sardjito Yogyakarta. Jurnal Gizi Klinik Indonesia 2010;7(1):1-7.

33. Serpa LF, Kimura M, Faintuch J, Coconello I. Effects of continous versus bolus infusion of enteral nutrition in critical patients. Hosp. Clin.Fac.Med.S.Paulo.2003; 58(1):9- 14.

34. Rock CL, Goldman L, Ausiello D. Saunders. Nutrition in the Prevaletion and treatment of disease. In: Cecil Textbook of Medicine 22nd; Philadelpia : Saunders; 2004.

35. Bisri T. Terapi nutrisi pada pasien cedera kepala berat. In : Penanganan neuroanestesia dan cricital care cedera otak traumatik. Bandung: Saga Olahcitra. 2012; p. 229-40.

36. Campos Machado FS. (2012). Nutrition therapy in severe head trauma patients. Bras Ter intensive. 2012; 24(1):97105.

37. Chen Y, Liu BL, Shang B, Chen AS, Liu SQ, Sun W, Yin HZ, Yin JQ, Su Q. Nutrition support in surgical patients with colorectal cancer. World J Gastroenterol 2011;17(13):1779-86.

38. Ward N. Nutrition support to patients undergoing gastrointestinal surgery. Nutr J 2003;2:18

39. Gramlich L, Kichian K, Pinilla S, Rodych N. Does enteral nutrition compared to parenteral nutrition result in better outcomes in critically ill adult patients? A systematic Review of the liferature. Nutrition.2004; 20 : 843-8.

40. Supriyadi Bektiwibowo, Zakiudin Munasir, Sri Sudaryati Nasar. Pemberian Nutrisi Enteral kasus Bedah Anak: Pengaruh pada Status Nutrisi. Sari Pediatri.2005;7(3): $136-142$

41. Galban C, Montejo JC, Mesejo A, et al: An immuneenhancing enteral diet reduces mortality rate and episodes of bacteremia in septic intensive care unit patients. Crit Care Med 2000; 28:643-648

42. Paul E. Marik, MD, FCCM; Gary P. Zaloga, MD, FCCM. Early enteral nutrition in acutely ill patients: A systematic review. Crit Care Med 2001; 29(12): 2264-2270

43. Gibson S. Principles Of Nutrisional Assesment Second Edition, Oxford University, Press Inc, New York; 2005

44. Restiana, Nurpudji A. Taslim, Agussalim Bukhari. Pengaruh Pemberian Ekstrak Ikan Gabus Terhadap Kadar Albumin Dan Status Gizi Penderita HIV/AIDS Yang Mendapatkan Terapi ARV. 2014. Available from : URL : http://pasca.unhas.ac.id/jurnal/files/5db462c0f32abe0c1e b16ec41c4ecf5e.pdf. 